\title{
GEOSPATIAL TECHNIQUES FOR EFFICIENT CONSERVATION AND MANAGEMENT OF SURFACE WATER FOR IRRIGATION IN JOGANBEDI VILLAGE, KHARGONE DISTRICT, MADHYA PRADESH, INDIA
}

\author{
Anand Mohan Singh ${ }^{\mathrm{a}}$, Abhishek Singh Chauhan ${ }^{\mathrm{a}}$, Devendra Aggarwal ${ }^{\mathrm{a}}$
}

${ }^{a}$ RMSI Private Limited, A-8, Sector-16, Noida-201 301 - (anand.singh, abhishek.chauhan, devendra.aggarwal)@ rmsi.com

KEY WORDS: Remote Sensing, Landuse/Landcover, Irrigation, Joganbedi, Narmada Basin

\begin{abstract}
:
The study aimed at developing improved methods based on remote sensing and GIS techniques to increase cultivated area under irrigation. Landuse / landcover mapping was considered as the key component to prioritize locations for constructing appropriate recharge structures. Joganbedi scheme was proposed for this study. Joganbedi is situated $13 \mathrm{~km}$. from Khargone, district Khargone, Madhya Pradesh, India. Command area of the proposed scheme lies in Beda sub-basin which is a tributary of the Narmada River. This area is of hard rock terrain and is occupied by the Deccan basalt. The main objective of the study was surface water conservation and management via multi-spectral information resulting from remotely sensed data to increase irrigation. High resolution GeoEye1 stereo images were used for generation of DEM, contour, landuse/landcover mapping, lineaments and drainage mapping. DEM was used for canal alignment. and further, contours were used to determine catchment, submergence /FRL, and command areas. Landuse/landcover statistics of submergence area helped to identify different land classes within the study area. These parameters are required for scheme planning. Additionally, rainfall data, maximum drawdown level, and dam height were collected as supporting parameters. The study concludes that landuse/landcover mapping is useful in identification of surface water conservation and management plan for irrigation purpose. It also proves that implementation of Joganbedi scheme will increase the cultivated area under irrigation, facilitate the farmers for multi season cropping and help in improving their economic condition.
\end{abstract}

\section{General Introduction:}

Integrated approach of Remote Sensing and GIS technology is powerful tool for conservation and management of surface water resources. Due to availability of very high resolution satellite images, it becomes possible to map very small features of the earth surface to carry out micro level planning and management. In order to obtain maximum benefits from technological development, it is imperative that the natural resources, soil and water be properly protected and judiciously utilized to improve their productivity constantly. Surface water conservation is in demand as water resources helps in agricultural and industrial development, to create and increase incomes and wealth in rural areas as well as fulfill daily need. In India more than $75 \%$ of population depends on agriculture for their livelihood. Agriculture plays a vital role in ours country's economy.

The current study aimed at developing improved methods based on Remote Sensing and GIS techniques to increase cultivated area under irrigation. Landuse / landcover mapping has been considered as the key component to prioritize locations for constructing appropriate recharge structures. Joganbedi scheme has been proposed for this study.

The land cover has been interpreted and mapped using Remote Sensing techniques from which land use has been inferred particularly with ancillary data or priority knowledge. Environmental factors such as soil characteristics, climate, topography, and vegetation control Landuse. It reflects the importance of land as a key and finite resource for most human activities including agriculture, industry, forestry, energy production, settlement, recreation, and water catchment and storage satellite images play a vital role for identification of land use/land cover mapping.

The methods of classifying Remotely Sensed images are based upon statistical classification of single pixels in a single digital image (Lillesand and Kiefer, 2004). Landcover mapping serves as a basic inventory of land resources for all levels of government environmental agencies and private industry throughout the world (Vijith, H. and R. Satheesh, 2007).

The complexity of this arrangement multiplies as nationally available water resources go depleted and nations forced to look beyond their own borders to meet the demand for water to satisfy multiple needs (Collins, R, 1990). Although GIS and remote sensing technology have only been around for not too long, they have emerged as valuable tools in natural resources management. Accordingly, geospatial information tools of GIS and remote sensing have already found widespread use in the areas of as forestry, water management as well as resource planning during environmental crisis (Twumasi, Y. A, 2005). Relative to other forms of water harvesting, such as ground water and small dykes, dams reduce the fixed cost of accessing irrigation in the command area (Biswas and Tortajada 2001 and Dhawan 1989). Unaffected land in the catchment area upstream to the reservoir is unlikely to benefit from dam irrigation, as lift irrigation is rarely practiced for dams (Thakkar, 2000). In fact, government agencies, which control the flow of water (through the opening of gates and sluices and the control of water pumping sites), typically maximize water distribution through the canal network, and to achieve maximum water storage in the reservoir, often restrict water use upstream from a dam. 
The main aim of present study is to investigate and identify Tank location which will help in irrigation throughout area of interest. Satellite images play a vital role in creating Landuse/Landcover map, DTM, Drainage map and Contour Map.

\section{Location of Study area}

The study area Joganbedi is situated at the distance of $13 \mathrm{~km}$. from Khargone, district Khargone, Madhya Pradesh, India. The study area is situated between Latitude $21^{\circ} 44^{\prime} 54.327 " \mathrm{~N}$ and $21^{\circ} 39^{\prime} 36.816^{\prime \prime} \mathrm{N}$ to Longitude $75^{\circ} 35^{\prime} 41.841^{\prime \prime} \mathrm{E}$ and
This study is helpful for increase irrigation facilities for farmers whom livelihood is depend on farming.

The present study is an attempt using Remote Sensing and GIS techniques to propose various water harvesting structures in order to suggest integrated land and water resource development

$75^{\circ} 44^{\prime} 59.48$ "E and falls in Survey of India Topo sheet No `$46 \mathrm{O} / 10$ (Fig - 1). The Average annual rainfall of the area is $650 \mathrm{~mm}$ to $700 \mathrm{~mm}$. The mean maximum and minimum temperatures recorded in the area are $40^{\circ} \mathrm{C}$ degree and $5^{\circ} \mathrm{C}$ respectively.

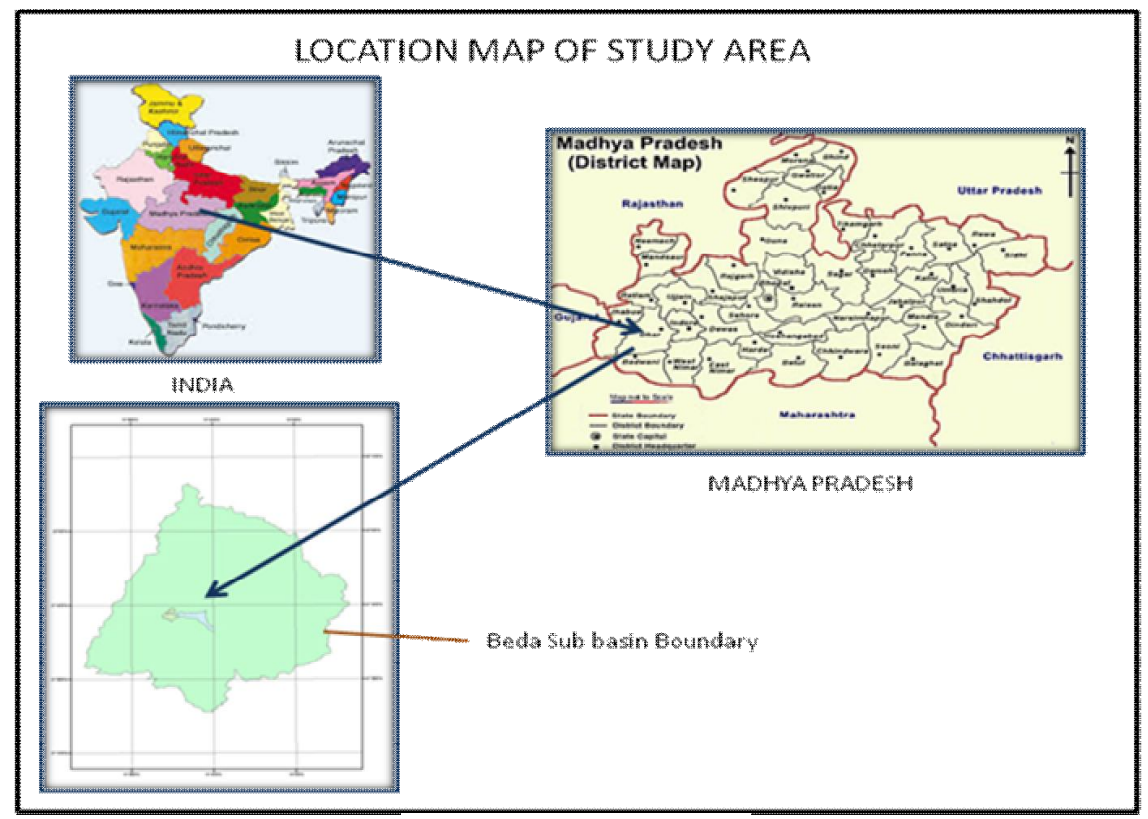

Figure no.1: Location Map

\section{Material and Methods:}

For the present study, Survey of India Topographical map on the 1:50,000 scale and high resolution GeoEye I (0.5 meter resolution) image has have been used.

To achieve the objective, integrated approach with convergence of evidences has been adopted in present study. Collection of rainfall data and other collateral data covering the of study area, preparation of based map and land use/land cover on 1:4000 scale using GeoEye imagery, surface water bodies, preparation of DTM and contour map of 1 meter contour interval using high resolution stereo pair, aspect and relief map from DTM, preliminary pre-field interpretation of hydro-geomorphology using satellite data, verification of doubtful areas and corrections are main emphasis parts within adopted methodology. The proposed Joganbedi scheme is based on feasibility reconnaissance surveys. The overlap of the proposed command area with any nearby irrigation schemes was avoided. For the studies, the interpolated contours of $1.0 \mathrm{~m}$ were generated using GIS techniques based database of images. The interpolated contour map was used to work out the details of the proposed schemes.

To achieve the above objective, methodology and procedure adopted in present study has been completed in three stages. In the first stage all data has been converted in digital form by digitization of existing maps like toposheet. From toposheet drainage network was initially digitized and finally updated with GeoEye satellite imagery. In second stage different thematic layer generated from source geo eye imagery like DTM generation, orthorectification, Landuse/Landcover mapping, and contour generation have been carried out. In third stage all layers were integrated and analyzed in GIS platform and used to finalize tank location by giving weights to different layers by giving special reference to Landuse/Landcover map. The Joganbedi scheme has been proposed on feasibility.

Methodology has been illustrated in figure no.2 


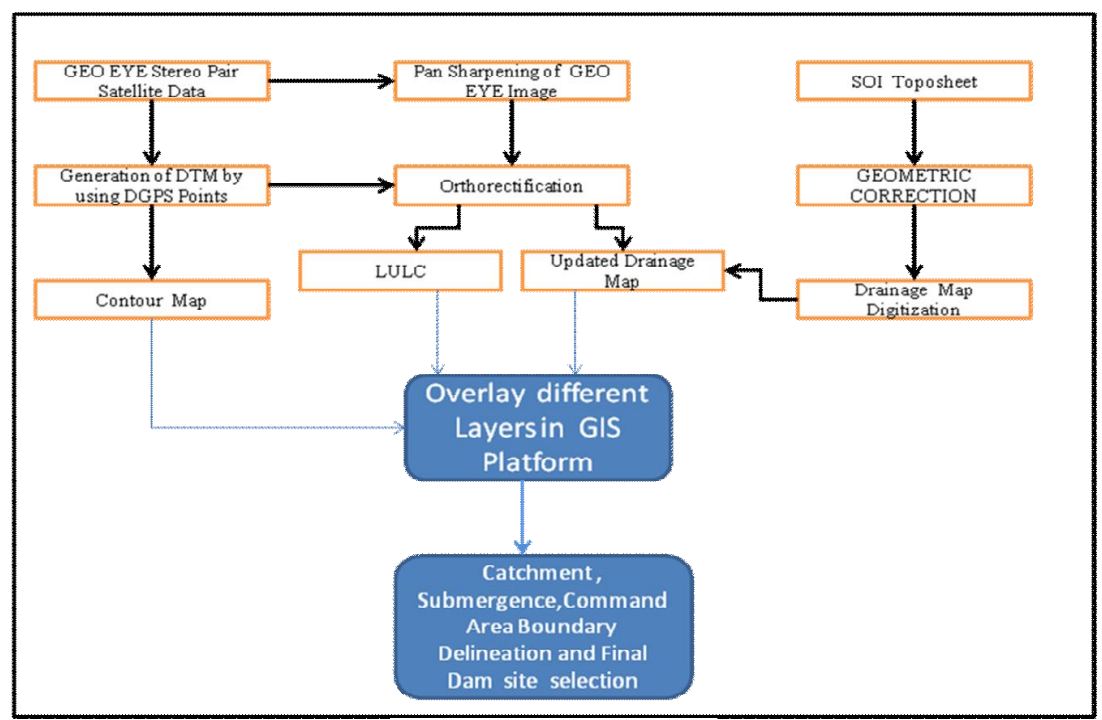

Figure no.2 Methodology

\section{Results}

On the basis of satellite data examination six classes of landuse have been classified on the fundamental of level I classification, considering RUIS standards. These demarcated classes are Agriculture, Builtup, Open/Scrub land, Road, Wasteland and Water body. LanduselLandcover mapping results shows Agriculture of $73.4 \%$, Builtup of $0.35 \%$,Open/Scrubland of $23.66 \%$, Road of $0.69 \%$, Wasteland of $0.07 \%$ and water body of $2.09 \%$ in entire area. Landuse/landcover statistics has been shown in Table 1:

Table 1: Landuse/Landcover statistics of Entire area

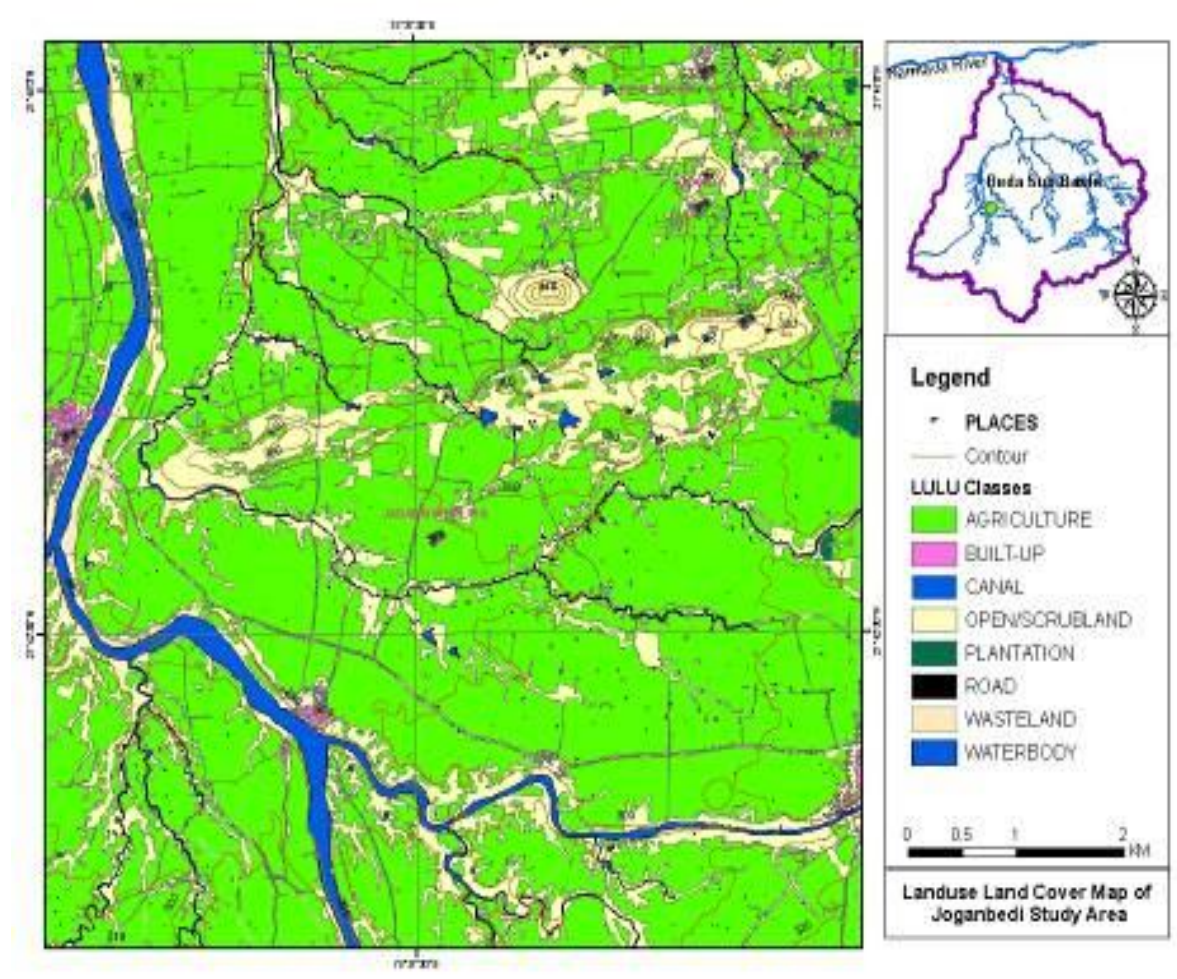

Figure no. 3: Landuse/Landcover Map of the study area 


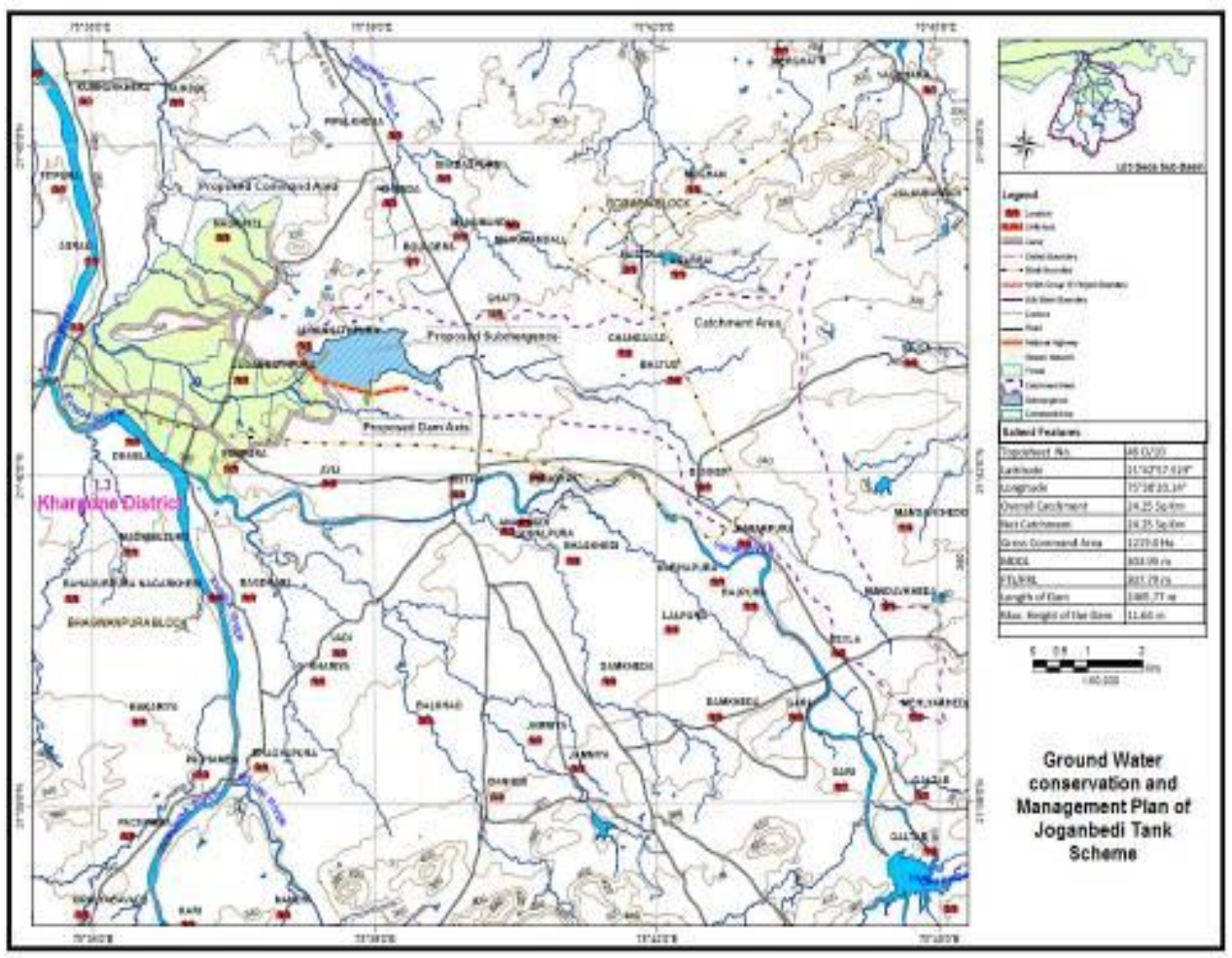

Figure no.4 Map showing Surface Water conservation and management plan of study area

In the Joganbedi study area for the surface water conservation and management plan a dam structure site has been selected. Dam site has been divided into four parts such as submergence area, command area, dam axis and catchment area

Joganbedi Tank is situated at Latitude $21^{\circ} 42^{\prime} 57.529^{\prime \prime}$ and Longitude $75^{\circ} 38^{\prime} 20.14^{\prime \prime}$, catchment area 24.945 Sqkm, Command area is 1219.0 ha, minimum draw down level (MDDL) -303.95m, Full reservoir level (FTL/FRL) $307.79 \mathrm{~m}$, Length of dam $2344.74 \mathrm{~m}$, max height of dam $11.64 \mathrm{~m}$.

Selection of Joganbedi dam site on the basis of LULC Statistics of submergence area is feasible because no forest area falls under submergence area.

The salient features of Joganbedi tank scheme are catchment area-24.945 sq.km, gross command area- $1219.0 \mathrm{Ha}$, minimum draw down level (MDDL)- $303.95 \mathrm{~m} \mathrm{~m}$, full reservoir level (FTL/FRL) - 307.79m, length of dam- 2344.74 $\mathrm{m}$, max. height of the dam $-11.64 \mathrm{~m}$.

The available 51 years annual rainfall data of Joganbedi area have been analyzed. Based on data series, the rainfall at $75 \%$ dependability has ascertained as $586.2 \mathrm{~mm}$. The maximum, minimum and mean rainfall is $1335.3 \mathrm{~mm} ; 118 \mathrm{~mm}$ and 760.2 $\mathrm{mm}$ respectively. The Yield calculated using Binnie's yield table corresponding to the maximum, mean and $75 \%$ dependable rainfall are respectively1.852 MCM758.35 MCM and $0.523 \mathrm{MCM}$. Storage reservoir proposed on stream falling in the drainage area, which will be feeding the main canal off taking from the Joganbedi storage scheme. Area of available
Table 1: Landuse/Landcover statistics of Submergence area

\begin{tabular}{|l|l|l|l|}
\hline S.N. & Class & $\begin{array}{l}\text { LU/LC } \\
\text { Statistic (Ha) }\end{array}$ & Area (\%) \\
\hline 1 & AGRICULTURE & 116.2685 & 79.9972 \\
\hline 2 & BUILT-UP & 0.1457 & 0.1003 \\
\hline 3 & OPEN/SCRUBLAND & 24.9810 & 17.1879 \\
\hline 4 & Plantation & 0.7038 & 0.4843 \\
\hline 5 & WASTELAND & 0.3987 & 0.2743 \\
\hline 6 & WATERBODY & 2.8430 & 1.9561 \\
\hline Total & & $\mathbf{1 4 5 . 3 4 0 7}$ & $\mathbf{1 0 0}$ \\
\hline
\end{tabular}

contours and DEM has been computed using GIS module. Areas at intermediate levels and corresponding gross capacity calculated by the usual method.

As this tank is required to cover the deficit irrigation requirement during non-filling period, all the available $75 \%$ dependable storage from the site is contemplated to be stored. Gross capacity for the proposed storage scheme is $0.42 \mathrm{MCM}$. The corresponding capacity at LSL is $0.065 \mathrm{MCM}$, MDDL is $0.093 \mathrm{MCM}$ and FRL is $0.42 \mathrm{MCM}$ respectively. The Total area under submergence is $145.3407 \mathrm{Ha}$ and total cultivated area under submergence with respect to the designed FRL is $116.268 \mathrm{Ha}$. The main canal which is contour or ridge is designed to carry a maximum discharge of 0.039 cumecs at head is $2.87 \mathrm{~km}$ long. 


\section{Discussion}

At present, in Joganbedi area, the crop cultivations are totally dependent on rainfall and it is subjected to vagaries of monsoon. Providing irrigation will improve the economic condition of the farmers and result in efficient utilization of soil and water resources of the region. Water distribution in the command area of Joganbedi Dam is proposed via artificially constructed canal. The command area lies downstream from the reservoir, with the canal extending in the downstream direction along the main stream and covering parts of villages. The effects of dam on agricultural production in the neighboring downstream village have been unambiguously positive.

\section{Reference}

\section{Journal Reference:}

- Biswas, Asit; and Cecilia Tortajada. (2001) Development and Large Dams A Global perspective, "International Journal of Water Resources Development; 17(1), 9(21).

○ Nobi, E.P; Umamaheswari, R; Stella, C; and Thangaradjou, T. (2009) Land Use and Land Cover Assessment along Pondicherry and its Surroundings Using Indian Remote Sensing Satellite and GIS. J. American-Eurasian Journal of Scientific Research; 4 (2), 54-58.

- Schiewe, J; Tufte, L; Ehlers, M; (2001) Potential and problems of multi-scale segmentation methods in remote sensing GIS. J. Zeitschrift fur Geoinformations system; 34-39.

○ Vijith, H; and Satheesh, R; (2007) Evaluation of Land use Pattern and Geomorphology of Parts of Western Ghats using IRS P6 LISS III Data. J. AG; 88,14-18.

\section{Book Reference:}

- Collins, R. (1990) Waters of the Nile. Hydropolitics and the Jonglei Canal 1900-1988. Oxford, Clarendon Press UK,

- Lillesand, T.M. and Kiefer R. W. (2004) Remote Sensing and Image Interpretation. 4th edition, John Wiley \& Sons, 132-160 p, New York, USA.

\section{Article Published in Proceedings}

- Dhawan, B.D. (1989) The Big Dams, Claims and Counter Claims, Commonwealth, New Delhi.

- Thakkar, Himanshu. (2000) Assessment of Irrigation in India,World Commission of Dams.
Land use/Land cover mapping of Joganbedi and surroundings area it found that the physical condition of soil and terrain are positive for multisession crop.

\section{Conclusion}

The present comprehensive study revealed that Joganbedi study area has an excellent location for surface water conservation and management plan. The gross command area is of $1219.0 \mathrm{Ha}$, so this scheme is effective for irrigation purpose of surrounding villages. It has been found that Remote Sensing coupled with GIS can be effectively used for real time and long term systems. The land use/ land cover pattern mapping of the area would be enormous facilitate for development and management plan. This complete study proves that implementation of Joganbedi scheme will increase the irrigation by $52 \%$ of existing irrigation and facilitate formers for multi season cropping.

- Twumasi, Y. A; Manu, A; Coleman, T. L; and Maiga, I. A. (2005) The Impact of Urban Growth and Long-term Climatic Variations on the Sustainable Development of the City of Niamey, Niger. In Proc. of the IEEE Int. Cof. Geoscience and Remote Sensing Symposium (IGARSS). vol.II., 1500- 1503 p, July25-29. Seoul, South Korea. 